\title{
Slit-lamp handling: Learning upgrade with webcam video recordings
}

\section{Manejo de la lámpara de hendidura: Mejora del aprendizaje con el uso de cámaras web}

\author{
Ana Gargallo $(\mathrm{S})$, Justo Arines $\left({ }^{*}, \mathrm{~S}\right)$ \\ Departamento de Física Aplicada (Área de Optometría) Universidade de Santiago de Compostela, Facultad \\ de Óptica y Optometría (Campus Vida), CP: 15782 Santiago de Compostela, Spain. \\ ${ }^{*}$ E) Email: justo.arines@usc.es \\ S: miembro de SEDOPTICA / SEDOPTICA member \\ Received / Recibido: 04/04/2014. Revised / Revisado: 20/05/2014. Accepted / Aceptado: 22/05/2014. \\ DOI: http://dx.doi.org/10.7149/OPA.47.2.163
}

\begin{abstract}
:
Slit lamp handling has always been difficult for students of the degree of Optics and Optometry in Spain. Instruments with associated cameras help a lot in this task. They allow teachers to observe and control students learning and performance. However, these devices are more expensive than those that do not have an integrated camera connected to a display unit. In this paper we present a cost effective alternative. We propose to place a webcam in one of the slit-lamp oculars (in our case, a Microsoft Lifecam HD-5000). The webcams are connected to a PC running Linux Ubuntu 11.0; therefore that is a low-cost device. The system was used during the teaching of slit-lamp handling in the practice of the subject of "Contactología I" of the degree in Optics and Optometry at the Universidade de Santiago de Compostela (Spain). The students were asked to complete a survey in order to test its usefulness. $90 \%$ of the students found the system very helpful. Our experience shows that with this simple approach we can do things easier: show the slit-lamp handling to all the students at the same time; take pictures or videos of different eye health conditions or exploratory routines for posterior visualization with all the students; increase the interactions between students allowing them to help and correct each other; and also record the final routine exam in order to make possible its revision with the students. We think that the presented option is a cost effective alternative to built-in cameras provided by slit lamp manufacturers for teaching purposes, supporting the training in optometry practice and increasing the student's confidence without a big outlay.
\end{abstract}

Key words: Slip-lamp, Optometry Teaching, Eye Health Examination.

\section{RESUMEN:}

El manejo de la lámpara de hendidura es una tarea que presenta un grado de complejidad significativo para los alumnos de la titulación de Óptica y Optometría. Cuando estos instrumentos incluyen cámaras para mostrar las imágenes se favorece el aprendizaje de su manejo. Las cámaras permiten al profesor observar y controlar el aprendizaje y manejo de estos instrumentos. Sin embargo las lámparas de hendidura con cámara incorporada, o la inclusión posterior de este accesorio, tienen un precio elevado. En este trabajo presentamos una alternativa de bajo coste. Proponemos el uso de una cámara web colocada en uno de los oculares de la lámpara de hendidura (en nuestro caso una Microsoft LifeCam HD-5000). La cámara web está conectada a un ordenador con sistema operativo Linux Ubuntu 11.0. El sistema se usó en las sesiones de aprendizaje del manejo de la lámpara de hendidura realizadas dentro de las prácticas de la asignatura de Contactología I del grado de Óptica y Optometría de la Universidade de Santiago de Compostela. Los estudiantes cumplimentaron una encuesta al terminar las prácticas con el fin de valorar la utilidad docente del sistema propuesto. El $90 \%$ de los alumnos encontraron el sistema muy útil. Nuestra experiencia muestra que este simple sistema hace la docencia más sencilla, permite mostrar el manejo de la lámpara a todos los alumnos de prácticas a la vez, hacer fotos y videos de diversos hallazgos oculares y rutinas de exploración para su posterior visualización con los alumnos, aumenta la interacción entre estudiantes permitiendo su autocorrección, además nos permite grabar las secuencias de 
exploración para su evaluación de cara a la calificación de las prácticas. Pensamos que el sistema propuesto es una alternativa de bajo coste que facilita la docencia del manejo de la lámpara de hendidura.

Palabras clave: Lámpara de Hendidura, Educación de la Optometría, Examen de la Salud Ocular.

\section{REFERENCES AND LINKS / REFERENCIAS Y ENLACES}

[1]. T. Grossvenor, Primary Care Optometry, $5^{\text {th }}$ edition, Butterworth Heinemann Elsevier, Boston (2007).

[2]. W. J. Benjamin, Borish's Clinical Refraction, $2^{\text {nd }}$ edition, Butterworth Heinemann Elsevier, St. Lois (Missouri) (2006).

[3]. A. Sulley, G. Young, K. O. Lorenzo, C. Hunt, "Clinical evaluation of fitting toric soft contact lenses to current non users", Ophthalmic Physiol. Opt. 33, 94-113 (2013). DOI

[4]. J. Veys, J. Meyler, I. Davies, "Essential contact lens practice, Part II: Slit lamp examination", Opticianonline 6 February (2007).

[5]. J. González-Cavada, Atlas de Lámpara de Hendidura Biomicroscopía Ocular, Ed. Complutense, Madrid (2000).

[6]. J. Arines, A. Gargallo, "Slit-lamp management in contact lenses laboratory classes: Learning upgrade with monitor visualization of webcam video recordings", in Proceedings ETOP 2013, M. Costa, M. Zghal, Edts., paper EWP15 (2013).

\section{Introduction}

Slit-lamp, also known as biomicroscope, is one of the most important tools in optometry and ophthalmology practice. It is a low-power microscope consisting of an observation system, which is a binocular microscope; an illumination system, which is a bright light source with a mechanism that allows controlling the width and orientation of the slit; and the mechanical support for its coordination [1].

In the daily practice, the optometrist uses the slit lamp to evaluate the health condition of the anterior segment of the eye by focusing the light in an ocular structure with the desired and oblique angle. The examiner should develop a routine that is repeated on each patient so that nothing is overlooked and all structures are inspected for abnormality. Examination routine also aids professionals to save time contributing to the patient comfort. An anterior-to-posterior approach should ensure completeness, and a specific procedure has been suggested [2]. In addition, the biomicroscope is useful in the assessment of contact lenses fitting [3,4], and other eye exams as tonometry, gonioscopy, eye fundus examination, etc. Therefore, it is very important for future professionals in the eye health care to learn the appropriate management of this instrument, which requires a lot of training [5].
In the Degree in Optics and Optometry of the Universidade de Santiago de Compostela (Spain) the students learn the theoretical principles of the slit lamp as an optometric instrument. Besides, they have to learn its management in a clinical environment in the contact lenses practice training. The practice sessions are organized in groups of 10 to 15 alumni, although the laboratory has only 4 slit-lamps. This means that in some sessions each slit-lamp should be used by three or more alumni.

In our laboratories the common way to teach slit-lamp handling was as follows: the teacher joins all the students in front of one slit-lamp; sits in front of it; describes the instrument (its parts, illumination arm, observation...); then the teacher shows how to proceed with the exploratory routine or do a specific technique. In order to show for example how to observe the endothelium of the cornea, the teacher looks through the binoculars, focus the slit-lamp, and call each student to observe through the binoculars while the teacher tries to keep the endothelium in focus. Our experience tells us that this procedure is frustrating for the student (usually they cannot see anything) and for the teacher that cannot show properly the endothelium to his students. We have observed that students do not understand very well the slit lamp handling and have a lot of problems 
with focusing (especially the cornea and the lens). These problems in the learning process generate a loss of confidence in the student that can lead to a discouragement to practice lessons.

In order to improve the slit lamp training of our students we developed a device. This device consisted of a webcam adapted to the slit lamp available in our contact lenses laboratory rooms, and connected to a PC. This is a low cost option to built-in cameras and it results very useful in the optometry and contact lenses practice teaching. Thanks to the webcams the teacher can show to all students simultaneously how to focus the slit-lamp on a structure (for example the endothelium), or how to perform a routine examination. Moreover, it enables the teacher to follow the progress of the students, watching how they focus and do the exploratory routine.

\section{Materials and methods}

\section{2.a. Materials}

We use USB HD webcams (Microsoft Lifecam HD-5000). The webcams are connected to a PC running Linux Ubuntu 11.0. The slit-lamps used where those placed in the contact lenses laboratory room and there are different models from different trademarks (Nidek LH1000, Nidek ALA-11, Takagi SM-70N). We manufactured different webcam to slit lamp ocular adapters with metal tubes with the correct section, internally covered with foam to avoid damage to the ocular surface (Fig.1(a)). The webcam was placed inside the tube in one side; the other side is adapted to one ocular with

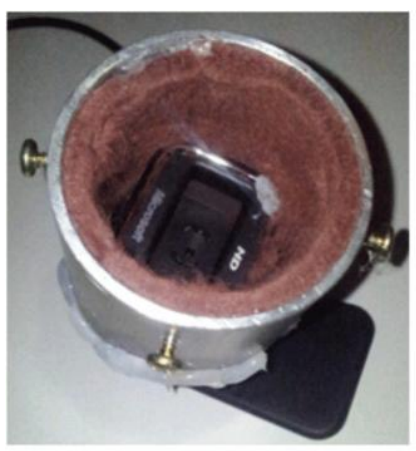

(a)

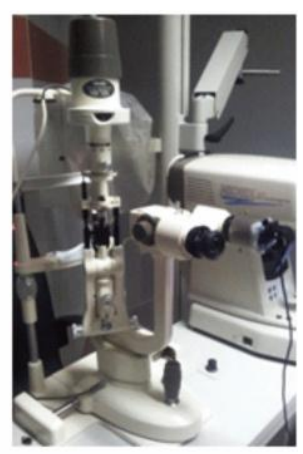

(b)
Fig. 1. (a) Image of the webcam with its adaptor; (b) Image of the slit-lamp with the webcam incorporated on the right hand ocular. four screws which allows easy placement and removal of the camera. In Fig. 1(b) we show the camera adapted to the slit-lamp ocular.

\section{2.b. Routine examination}

We provide students with a routine examination outline. This routine consisted in the evaluation of the eye starting with the exam of the eyelids and lashes with diffuse illumination, looking for alterations in lashes, meibomian glands, lids and tear meniscus. Diffuse illumination is used to observe the conjunctiva. After the conjunctiva they assessed the cornea and the tear film with parallelepiped illumination. Then iris and anterior chamber angle can be assessed, followed by examination of the crystalline lens with parallelepiped illumination too. The students were trained to the examination in less than 3 minutes.

\section{2.c. Evaluation of the method}

The practice period consisted of 4 lessons of 2 hours each. At the end, students were examined. During the exam each student had to explore the health of one eye of a classmate in less than 3 minutes by following the ocular examination routine described above. We assessed the handling skills, the correctness of the routine and the well-focusing during the eye health examination.

After the exam, the students were asked to answer a survey, with the aim of knowing their opinion about the use of webcams in the slitlamp handling training. They were asked to respond from 1 (nothing) to 5 (very high) the following questions: (1) difficulty in the management of the slit-lamp; (2) difficulty compared with other techniques; (3) reduction in training time; (4) utility of webcams during the learning process; and (5) increase in their confidence with the webcam support.

\section{Results}

Our first result is that teaching slit-lamp handling with the proposed device is easier. We had used them for different purposes: to explain the examination routine; to show the different anatomical structures of the eye and lids; to 


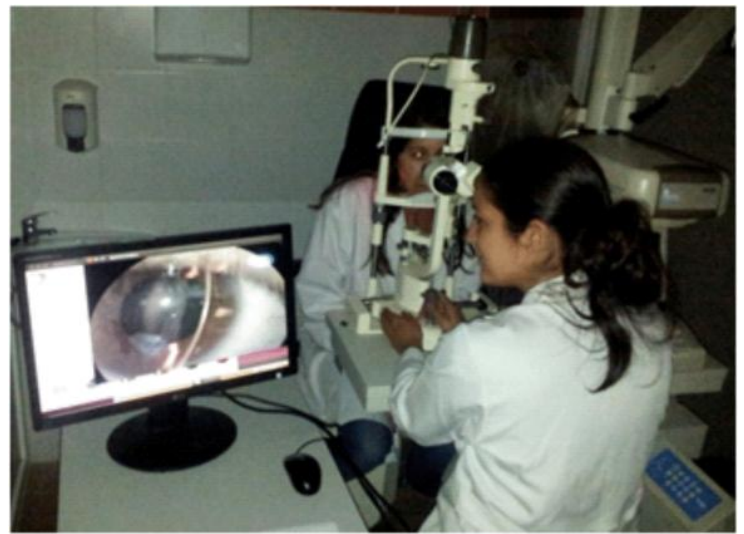

Fig. 2. Picture of a teacher showing the students how to make the exploration.

show the position and shape of the slit sections in the anterior and posterior surfaces of the lens; to teach the difference between a in-focus and out-of-focus section of the cornea; to record pictures and videos of examination routines; to record the final exams; and for collaborative learning between students allowing their selfcorrection. Picture in Fig. 2 shows a teacher performing and explaining the examination routine to the students.

At the end of the 4 training sessions, student made a final exam: 49 students were evaluated.
The exams were recorded. $80 \%$ of the students were able to do the exploratory routine in less than 3 minutes. We still observed that $18 \%$ had problems in focusing the slit-lamp on the lens and/or cornea.

After the exam the students completed the survey. Concerning the difficulty of the slit-lamp management, over $80 \%$ of the students found a degree of difficulty between medium and high (Fig. 3(a)); 62\% considered this technique harder to learn than others learned as topography, queratometry, retinoscopy, etc (Fig. 3(b)); about $50 \%$ of the students reported that the use of webcams reduced the learning period (Fig. 3(c)); 68\% of students considered that the use of webcams increased their confidence in the management of the slit-lamp (Fig. 3(d)). Finally, $90 \%$ of them found very helpful the use of this method in their training sessions (Fig. 3(e)).

The more commented difficulties in the use of the slit-lamp were: correct focusing of the cornea and lens; the control of illumination arm; and the selection of magnification with easiness. They found very helpful the use of webcams for the teacher's explanations concerning the observation techniques and the general management of the slit-lamp.

\section{Slit-lamp management difficulty}

|none || low || medium | high || very high

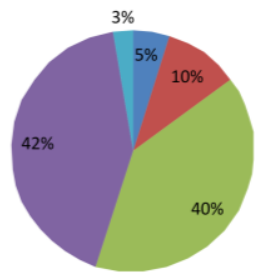

(a)

Reduction in learning time

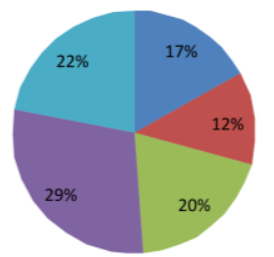

(c)

\section{Compared difficulty with other techniques}

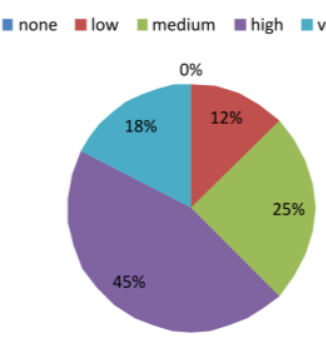

(b)

\section{Increase of self confidence}

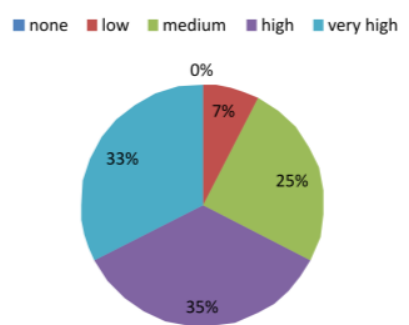

(d)
Webcam utility in learning process

| none | low || medium |

$0 \% 0 \%$

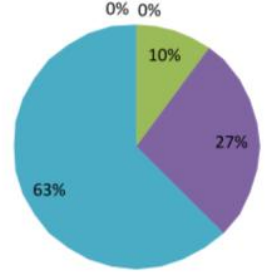

(e)

Fig. 3. Results of the survey. 


\section{Discussion and conclusions}

We observe that the webcam with the ocular adapter is a low cost method to help students in the handling of the slit-lamp, moreover this device allows teachers to take advantage of the available instruments in the laboratory. It is a useful technique to teach and make demonstrations of eye health evaluation [6]. We use the system to show the exploratory routine, show how students should see the different anatomical structures of the eye (in particular the cornea and posterior and anterior faces of the lens), record videos and pictures with abnormal anatomical findings, follow the improvement in the slit-lamp management of each students, and record examinations in order to show the students they errors. The proposal also encourages the interaction between students, when one of them is using the slitlamp, the others can follow his exploration and realize of mistakes, make corrections and being active with their learning instead of waiting passively until their turn. Students were comfortable with the use of webcam and recognized its helpfulness. Their confidence in practice was increased when they were controlled and corrected by teachers thanks to them.

In our proposal the webcam is only placed in one ocular, which does not allow binocularity through the oculars, but is a cheap option for those teachers that do not have the second observer tube included in their slit-lamps.
Although it could be a problem, the webcam can be easily removed in order to restore binocularity. In the case of introducing the students into slip-lamp training we think that, at least at the beginning, a good learning of focusing and understanding of how the ocular structures are seen through the instrument is more important than binocularity. The incorporation of a second observer tube in the slit lamp is an option to improve the teaching of slit-lamp handling. It allows the teacher and the student to observe simultaneously what the student is focusing, promoting the necessary feedback demanded by the student to gain confidence in the handling of the instrument. Additionally it is possible to place the webcam in this accessory providing both, binocularity to the observer and real time images to the rest of the audience. The simultaneous use of two webcams on both oculars provides the chance of recording and visualizing 3D videos when they are used with the appropriate steresocopic software (as for example StereoMove Maker). This possibility would be explored in the near future.

\section{Acknowledgements}

This work supported by the University of Santiago de Compostela, grant Convocatoria de axudas para o desenvolvemento de accións de mellora da docencia 2011, grant CN 2012/156 (Xunta de Galicia), Isidro Parga Pondal Programme 2009 and Plan I2C Programme Apoyo a la etapa Predoctoral (Xunta de Galicia). 